\title{
The Current Analysis of Protection Path of Farmers' Rights and Causes
}

\author{
Xinjie YANG \\ Luohe Medical College \\ Luohe,462000 China
}

\begin{abstract}
The problem of Chinese peasant in society is a very important issue in the process of China's legal system; the farmer is very worthy subject of rights concern. The author believes that China has the right to protect their farmers in three main ways: private relief, public relief and gray channels, which play a major role in the private relief for farmers. For these channels, they are a unique reason; the rule of law should be the vision and balance for them to choose their own presence in China.
\end{abstract}

\section{Keywords- Farmers' Rights; Protection; Relief}

\section{INTRODUCTION}

Most are farmers living in rural areas of China's population, and therefore the issue of farmers becomes Chinese an extremely important issue in society. Both in the eastern coastal areas, mountainous or remote and backward in the west, Chinese farmers due to its own economic status, cultural qualities impact of geographical conditions in modern society are often in the bottom of society, then how the farmers to protect their rights is a very important issue. The traditional concept of a number of local farmers is for ordinary thought and action Village (town) and the county's leading cadres have a huge impact, this historical inertia is often beyond people's imagination. Reform and opening up have brought new ideas, new concepts have impact on the surface to even the most remote Chinese village, but watching TV or driving motorcycle farmers would go to pray. Farmers are still in the way to solve the problem by means of habit in human, family relations, and other clan power, law, power of the state in the minds of farmers who felt emboldened enough. Chinese farmers are to realize the full protection of their rights and achieve real change from the villagers to citizens who still have a long way.

\section{A BASIC THEORY CONCERNING THE PROTECTION OF FARMERS' RIGHTS ISSUE}

About what is right, academia commentators have different viewpoints, farmers' rights referred to mainly refers to the interests of farmers as subjects of rights, including the material, spiritual and various personal interests (or can be divided into the production rights, political rights and personal rights, etc.), and that this interest is reflected, embodied and protected in the law.

Farmers as small producers, the most basic rights of individuals should be their private property ownership and the right of land contractual management. Farmers' political rights is the right to participate in major national social affairs management activities, including the right to vote, such as the right to stand for election and supervision; personal rights are mainly farmers as a social subject under the Constitution enjoy fundamental rights of the person, such as personality rights, liberty and the right to education, etc. In short, from the farmer's point of view as a social subject of a class point of view, they not only enjoy the Constitution and laws the fundamental rights provisions, including some rights for agriculture, farmers have set up a separate characteristics (such as land contract and management rights). Since farmers have rights, individual, collective, state and society should be ensured through a variety of ways that this right is realized, so that the rights of legal rights into reality. Therefore, safeguards the rights become more important.

The so-called rights protection is the prevention of rights that have been violated, and ultimately ensure that the rights of institutionalized protection. Throughout the Constitution and laws of the world, without exception, they are to protect the rights to be taken two ways, one is the right to declare, and the second is to provide the conditions for the realization of civil rights. Philosophically speaking, the right is not purely a physical specification, which is the result of subjective and objective unity that is the objective content (interest) and subjective form (will) result of unity. This unity freedom of expression or freedom of human behavior that people consciously realize or recognize their legitimate interests must be taken or the performance of socially allowed a proactive behavior to get it. To protect the rights of a specific attack is not only the rights of people to their obligations, but also the obligation to society, the rights of people to defend their rights by law and by the laws indispensable to the maintenance of social order. China now has many explicit laws to declare the rights of farmers, but it does not mean the right to declare the rights have been well protected, but also they need further specific protective measures, including farmers own habit of accredited civil protection and official measures of protection provided by the State. For this measure (way), what we want to know is how farmers to face them, rather than relying on the legal theory of our own habits to what is imposed on them. 


\section{PRIVATE RELIEF AND ANALYSIS OF THE CAUSES OF FARMERS' RIGHTS}

Relief in the way of the ordinary farmers rights violations, generally will use private relief, the so-called right of private relief refers to the general rights of farmers in their own destruction, which mainly rely on the power of an individual or family and friends to be protected,

This approach has its unique reason in China, affecting the traditional habit, the enactment can say a lot, but in some rural areas, people's behavior is more in accordance with long-standing habit formation that was not in accordance with the provisions of the law. Currently, many scholars are holding such a view that China is the local community; local community in practical effect is often the customary law in countryside. For example, the issue of succession is to property in the rural areas and so the traditional habit of thinking and reflecting have the impact of the current practice in rural areas. "Tradition has always been a real force, both recorded in ancient books being, but it is also to live in people's minds, customs and behavior among and direct impact on the actual operation of the system, no matter what kind of system is the modern name."Chinese people always attach importance to the role of the human family, and this tradition in modern people and not much change, whether rural or urban, but in rural areas are clearer. In the right relief, private relief is the way in the minds of farmers still weighs heavily, although they may not know what a "private relief" and traditional Chinese culture are to pursue legal values that can be said to be "no litigation ". In a sense," no suits "can even be said to be the ultimate values and ideals, which led to the fact that Chinese farmers have always been there," which is tired of complaints, "the tendency is always to court to resolve disputes in a less glorious thing, generally they do not put it that way as the first choice. In the more closed, less liquidity and smaller rural communities, using litigation to resolve this issue will result in a difficult contradiction to bridge, which is the kind of lifestyle that is not suited to local community. So, in this traditional role, the majority of Chinese farmers are in the protection of their rights, the first choice is not the power of the national government, but private power and proliferation as a center circle of acquaintances or friends or relatives.

Private relief from the perspective of the analysis into the wood look has a cost of small high-return characteristics. If the villagers are resolving disputes, protecting the rights because of the time, money and the impact of their investment relationships are seen as a cost. For time saving and money saving, relationships and improve maintenance is income. Compared to public relief, private relief in this regard is of great advantage. According to assume legal and economic analysis, people are always rational to maximize their satisfaction, all the people involved in all their activities will have such choice. China's farmers due to the nature of its small producers have the self-interest of "preoccupied" to protect their rights in the treatment, although a lot of time is a conscious act. Cost savings in the following points: (1) short time compared with the litigation, higher efficiency. (2) private relief can overcome economic barriers. (3) maintain relationships, as mentioned earlier, farmers choose private relief, which is a tradition, they want to keep the "precious" traditions, this practice of maintaining good relationships is o a cost saving. Local society is an important resource for mutual acquaintance that has the same information symmetry. In the case of symmetric information, it can reduce transaction costs; can fully predict based on their own information with each other as well as the consequences of their actions that will happen to others according to their behavior reaction. The lawsuit is meant to break a relationship; in the formation of asymmetry of information, the information asymmetry can affect each person's behavior, thereby affecting the various exchanges, increasing the opportunity cost of future activities. An important reason for the farmers prefer external private relief of the country's judicial way or public relief supply shortage, or it can be said that due to the weakening of national jurisdiction in the countryside. In China's vast rural areas in a sense you can say that the margins of state power, especially in the judiciary, the judicial power of the State cannot effectively penetrate deep into the countryside, into the concept of farmers. This aspect is reflected in the judiciary that is a serious shortage of the number of peasants, and even in the vast rural communities rarely that have a qualified lawyer (solicitor made official). Farmers own the rights specifically, what kind of rights will be suffered damage, and how to resolve disputes through litigation that this problem is not a clearer understanding; the role of the court is not able to clearly identify. This problem occurs mainly because the judiciary has not enough supply from the country. County court is the most basic Chinese courts that also handle most court cases. Civil cases of first instance from the most direct contact with the lives of ordinary people view, this ratio is not less than $90 \%$, but in the number of judicial officers, which is very small (the 2001 "law Yearbook of China," China now has more than 215,000 prosecutors, less than 30 million judicial officers. While China is accounted for more than a year nationwide cases of first instance case to the number of $90 \%$, and the quality of the judges of the lower courts is generally low, if the education measures. The judges of lower courts have been very few formal legal educations Bachelor of law Education, which is coupled with the court of their numerous constraints on the role of grassroots courts in protecting the rights of farmers in rural areas to resolve the dispute. So before China's rural economic model, social organization and not a fundamental change in the mode of operation, the power of the country (can be specific to jurisdiction) is easily seen as an ordinary farmer who was forced to use an external force, and often in conflict with a spontaneous look on it.

Private relief is to protect the rights of farmers that played a big role, but the lack of force, the other party can be denied or for rights holders against the conduct in this case, "public relief" effect on manifested.

\section{Public Relief AND ANALYSis of the CAUSES OF FARMERS' RIGHTS}

Public relief is through litigation, mediation and court administrative reconsideration ways to protect their rights. I 
called the public relief here mainly because farmers are through the national judicial authority of the use of executive power by means of power of the state to realize the rights guaranteed. To protect their rights is through litigation (lawsuit), although it is not farmers generally accepted way, but because it is on the public or the community as a whole concept that the normal channels, farmers generally do not deny or firmly rejected. China at this stage, especially after the reform and opening up has a wide range of legal advocacy, legal education prosperity, law highlights is the role of ordinary people's lives which have in large part to the idea gradually be recognized and strengthened through litigation to resolve dispute that has been increasingly considered to be a normal thing. Compared with private relief for farmers, this road can be seen as second best option. Public relief has much private relief that does not have the advantage.

The main route of the public relief is proceedings; judgment is to resolve disputes through the courts. There are also administrative regulations and administrative reconsideration, but rarely in rural areas currently is being used. At this stage, with more detailed legislation in the country, we should gradually increase farmers' awareness of the law. With this factor, the minds of farmers are to reduce misunderstanding of the legal and judicial activities, making the majority of farmers rely on increasingly public relief, we can say, with the process of China's legal system, public relief will become an essential way to protect the rights of rural China, but it takes more time and effort.

\section{CAUSE OF WAYS OF GRAY FARMERS' RIGHTS PROTECTION ANALYSIS}

Gray ways mentioned here mainly refers to the method that does not comply with the law. Strictly speaking, the method is not consistent with the law that should not be considered to protect the rights of way, but these methods are to be applied frequently in reality, sometimes there is a great "market", so I tentatively be defined this way. These pathways include unlawfully abused private relief.

Unlawfully abused private relief and blind will revenge great similarity. Due to the specific provisions of the law, ordinary farmers poorly understood, but it is influenced by the concept of simple fairness, farmers generally tend to believe that their rights have been violated; you can take yourself for granted that various measures are to save, and even give each other equal retaliation, particularly in more obvious case of personal injury.

Gray pathway exists, not because of the construction of rule of law in China's rural areas that did not yield any resulted, because the concept is not entirely Chinese farmers stay in the feudal society, the most important reason is that the way is to protect farmers' rights and national jurisdiction of choice for rural penetration and ineffective control. In the current judicial system, and government agencies cannot properly protect their rights, or through normal channels to protect their rights when the cost is too high, farmers will not help that this is not a legitimate choice - sometimes it is recognized as customary way.

\section{CONCLUSIONS}

In short, gray way for democratic legal system in rural China caused a huge obstacle, contrary to the rule of law and the trend of the whole country, which should gradually be eliminated.

The concept of China as well as the formation of farmers' long-term behavior change requires a very long time process. Therefore, for the private relief habit in the state is to take advantage of this "local resources." For public relief, an important issue is to be addressed, which is how to solve the quality that is not high-level courts judge in the situation to improve in this area. That is to reduce the cost of public relief. Gray approach is to firmly be eliminated, but we also will find the key that is how to eliminate the role of a good private relief and public relief, which the legalization process in rural areas are inextricably linked.

\section{References:}

[1] Chen Youhua Improve farmers citizenship, accelerate the pace of ritual socialist new countryside construction [J]. Economist, 2008 (2) .210 .

[2] Gong Chunming, Liao Shuigen. On the New Rural Construction of new farmers to cultivate and shape [J]. PARTY BUILDING, 2006 (12).

[3] Gu Yikang. Urban and rural development, while promoting a ceremony socialist new countryside construction [J]. Chinese rural economy, 2005 (1) 06 